\title{
CONSTRUINDO E DESCONSTRUINDO ESCÂNDALOS DE CORRUPÇÃO: A OPERAÇÃO LAVA-JATO NAS INTERPRETAÇÕES DA VEJA E CARTA CAPITAL
}

\author{
Constructing and deconstructing corruption scandals: the Lava-Jato Operation \\ interpreted by Veja and Carta Capital
}

Túlio Gonçalves Gomes*

Cintia Rodrigues de Oliveira Medeiros**

\begin{abstract}
RESUMO
Neste artigo promovemos um diálogo entre a sociologia da corrupção e a sociologia dos escândalos objetivando identificar e analisar discursivamente os repertórios interpretativos das revistas Veja e Carta Capital sobre os escândalos de corrupção, especificamente na Operação Lava-Jato, em seu primeiro ano após a deflagração. Nós conduzimos uma pesquisa documental com abordagem qualitativa, reunindo reportagens sobre o caso em análise, e identificamos os três principais repertórios interpretativos das duas revistas. Os resultados apontam que a revista Veja constrói o escândalo com o intuito de fazer oposição frente ao partido de situação da época, o Partido dos Trabalhadores (PT). Já a Carta Capital tenta descontruir o escândalo defendendo que a mídia deveria apenas informar o leitor e não ser partidária de modo a influenciar o leitor eleitor.
\end{abstract}

Palavras-chave: Escândalos. Corrupção. Poder. Operação Lava-Jato.

\begin{abstract}
In this paper, we promote a dialogue between the sociology of corruption and the sociology of scandals, in order to identify and discursively analyze the interpretative repertoires of the magazines Veja and Carta Capital on corruption scandals in the case of the Lava-Jato Operation, in the first year after its outbreak. We conducted a qualitative documentary research, gathering reports on the case under analysis, and identified the three main interpretive repertoires of the two magazines. The results indicate that Veja constructs the scandal in order to oppose the situation party, the Workers' Party (PT). Carta Capital, however, attempts to deconstruct the scandal by arguing that the media should only inform the reader and adopt a non-partisan stance, in order not to influence the elector reader.
\end{abstract}

Keywords: Scandals. Corruption. Power. Lava-Jato Operation.

\footnotetext{
* Mestre e Graduado em Administração pela Universidade Federal de Uberlândia (UFU) - Uberlândia (MG), Brasil. E-mail: tuliogomes@ufu.br. ORCID: 0000-0002-3876-962X

** Professora do Programa de Pós-graduação em Administração da Universidade Federal de Uberlândia (PPGA/ Fagen/UFU) - Uberlândia (MG), Brasil. Doutora em Administração pela Fundação Getúlio Vargas (FGV). E-mail: cintia@ufu.br. ORCID: 0000-0001-7999-9002
} 


\section{INTRODUÇÃO}

A corrupção é um fenômeno que afeta todo o mundo, existindo várias definições para o termo, sendo a maioria relacionada à ideia de que o agente que pratica a corrupção sempre recebe algum tipo de benefício em troca. Segundo a Transparência Internacional, a corrupção é definida como o abuso de poder confiado a alguém visando benefício pessoal, e pode ocorrer tanto em altos níveis de políticas governamentais quanto nas relações do dia a dia entre servidores públicos e cidadãos comuns (TRANSPARENCY INTERNATIONAL, 2015).

Os impactos da corrupção são diversos, como, por exemplo, os custos envolvidos, os quais, no pior dos casos, incluem até mesmo vidas. Ainda, a corrupção custa a liberdade, a saúde e os recursos de um povo, sendo um obstáculo para a democracia e para o desenvolvimento econômico (TRANSPARENCY INTERNATIONAL, 2015). A organização Transparência Internacional elabora, anualmente, o Índice de Percepção da Corrupção, que mede as percepções sobre a corrupção em 168 países. No índice de 2015, a Dinamarca lidera pelo segundo ano consecutivo como o país com a menor percepção da corrupção, enquanto o Brasil ocupa a $76^{a}$ posição, juntamente com países como Índia e Tailândia (TRANSPARENCY INTERNATIONAL, 2016).

Os casos de corrupção existem nos mais variados setores, porém esses se tornam escândalos públicos a partir do momento em que a mídia começa a investigá-los e os leva ao conhecimento da sociedade em geral. A forma como a mídia trata o caso de corrupção é que determina se esse virá ou não a se tornar um escândalo de grande repercussão (JACOBSSON; LÖFMARCK, 2008). Isso porque a transgressão que leva ao escândalo sempre existiu, porém, o impacto causado na sociedade depende da extensão e abrangência da cobertura por parte da imprensa. Através das denúncias de esquemas de corrupção, as imprensas nacional e internacional produzem diferentes sentidos a respeito das ações corruptas que se manifestam dentro dos diversos tipos de organizações (SILVA et al., 2005).

Entendendo que a sociologia da corrupção está imbricada com a sociologia dos escândalos, e que os escândalos de corrupção afetam diretamente a gestão das organizações, nosso objetivo neste artigo é identificar e analisar discursivamente os repertórios interpretativos das revistas Veja e Carta Capital sobre os escândalos de corrupção, no caso da Operação Lava Jato, no primeiro ano após a sua deflagração. Nós conduzimos uma pesquisa documental com abordagem qualitativa, reunindo reportagens sobre o caso em análise. No início do ano de 2014, um esquema de corrupção veio à tona no Brasil quando uma força-tarefa, a Lava-Jato, foi instituída pela Justiça Federal de Curitiba para investigar quatro organizações criminosas lideradas por doleiros, descobrindo um esquema de corrupção em curso há mais de 10 anos, envolvendo a Petrobras (MPF COMBATE A CORRUPÇÃO, 2015).

Segundo balanço divulgado pelo Ministério Público Federal (MPF), atualizado no dia 07 de novembro de 2016, os números da operação após 37 fases da operação apontam, em primeira instância, para: 70 acordos de delação premiada com pessoas físicas, seis acordos de leniência firmados e um termo de ajustamento de conduta, pedidos de ressarcimento (incluindo multas) no valor total de $\mathrm{R} \$ 38,1$ bilhões, recuperação (através de acordos e bens bloqueados) de $R \$ 3,1$ bilhões dos $R \$ 6,4$ bilhões pagos em propinas, 
e 118 condenações, contabilizando até o momento 1256 anos, 6 meses e 1 dia de pena. Um estudo da Consultoria Tendências divulgado pela BBC (COSTAS, 2015) aponta que a operação Lava-Jato acarretou um impacto negativo de 2,5 pontos percentuais no produto interno bruto brasileiro no ano de 2015 , devido à redução de investimentos em setores essenciais para a economia brasileira.

Para além dos impactos econômicos-financeiros, os escândalos de corrupção mostram que a mídia pode influenciar as relações do público com as organizações envolvidas (CHOULIARAKI; MORSING, 2010). Nossa justificativa para a realização desta pesquisa vai ao encontro dos estudos sobre a dinâmica das interações entre a mídia e as organizações, ao apontarem que a mídia de massa, a imprensa, a televisão são centrais para a construção e desconstrução da identidade, da imagem e da reputação de uma organização, tendo o debate sobre as promessas e os riscos da visibilidade da organização se intensificado nos últimos anos em virtude da emergência das mídias sociais (CHOULIARAKI; MORSING, 2010).

Diante desse contexto, é relevante compreender como o escândalo de corrupção afeta a gestão no setor público e privado, bem como os partidos políticos, um tipo de organização que é impactado fortemente quando a transgressão vem a público. Depois desta introdução, prosseguimos tecendo um diálogo entre duas abordagens teóricas: a sociologia do escândalo e a sociologia da corrupção. Em seguida, descrevemos os procedimentos de pesquisa adotados, apresentamos os resultados e encerramos com nossas conclusões.

\section{CORRUPÇÃO E ESCÂNDALOS: ABORDAGENS CONCETUAIS E TEÓRICAS}

Ao considerar o objetivo de identificar e analisar os repertórios interpretativos das revistas Veja e Carta Capital sobre os escândalos de corrupção, no caso da Operação Lava-Jato, buscamos estabelecer um diálogo entre a literatura da corrupção e do escândalo. Iniciamos então pelo amplo debate conceitual do termo corrupção, mostrando como o quadro teórico sobre o tema se constitui, porém, sem fazer uma opção teórica por uma das abordagens, visto que o objetivo se trata de analisar os repertórios das revistas, os quais podem indicar perspectivas distintas para o texto.

$\mathrm{O}$ debate conceitual sobre corrupção se desenvolve por diferentes perspectivas. Por exemplo, a corrupção é definida como uma forma de abuso da coisa pública que vise o ganho privado (OBEROI, 2014); como um processo canceroso que atinge todo o mundo, sendo derivada do mau uso do poder que foi confiado a alguém, ou o uso desonesto de um cargo ou posição social para atingir objetivos pessoais (IJEWEREME, 2015); como uma espécie de "[...] desvio de um padrão de conduta institucionalizado que se caracteriza principalmente pela utilização do público pelo privado com um manifesto propósito de favorecimento pessoal ou grupal" (SILVA, M., 1994, p. 21); como o abuso do poder (geralmente de governo) confiado a alguém para a obtenção de ganhos privados (BATABYAL; CHOWDHURY, 2015).

A corrupção pode ser interpretada de duas maneiras, sendo a primeira uma leitura moralista em que a decadência dos valores do indivíduo gera consequências adversas na sociedade, e outra em que a corrupção não está relacionada aos aspectos morais do indivíduo, mas, sim, à fraqueza das leis e instituições políticas (MARTINS, 2008). Huntington (1975, 
p. 72) relaciona a corrupção com o "[...] comportamento de autoridades públicas que se desviam de normas aceitas a fim de servir a interesses particulares". Em uma sociedade essencialmente corrupta, leis severas de combate à corrupção tenderiam apenas a aumentar as oportunidades para que os agentes pratiquem a corrupção, uma vez que novas leis poderiam definir como corruptas atividades que, anteriormente, não eram assim classificadas.

A corrupção possui uma forte conexão com o tema moralidade, visto que essa é um rompimento de normas que são constituídas a partir da construção de juízos morais do comportamento das pessoas e instituições (FILGUEIRAS, 2006). Nessa lógica dos juízos morais, a corrupção pode assumir quatro formas: (1) política, que considera as virtudes do corpo político, estando ligada ao decoro político frente aos princípios da ordem; (2) cultural, quando leva em consideração os costumes no juízo moral de valor, exigindo honestidade por parte do agente frente a potenciais corruptores; (3) social, os juízos morais tendem a vincular necessidades materiais à ação, sendo a corrupção uma usurpação, mediante ato violento, de bens por parte de agentes e instituições; e (4) econômica, que refere-se à ilegalidade da apropriação indébita de um domínio público (FILGUEIRAS, 2006).

Apesar da dificuldade em se estabelecer uma definição para corrupção, Nye (1967), Brei (1996), Hodgkinson (1997), Gardiner (2002) e Heidenheimer (1970, 1989) apresentam as definições reunidas em perspectivas e grupos, variando de acordo com o foco. O primeiro grupo é a perspectiva legal, em que as definições do que é corrupção se orientam pela lei, normas e outras regulamentações. Se um ato é proibido pela lei, é corrupto, e as diferenças legais entre nações dificultam um consenso de conceitos (HODGKINSON, 1997; BREI, 1996; GARDINER, 2002). Outra perspectiva apresenta as definições com foco no interesse público. Nela, o que realmente importa para um ato ser considerado corrupto é o interesse público, mesmo que este seja contrário às leis. Prevalecem fundamentos baseados na ética e na moral, considerando algo como correto na medida em que cumpre a finalidade para a qual foi criado (HODGKINSON, 1997; BREI, 1996; GARDINER, 2002; HEIDENHEIMER, 1970). Temos também a perspectiva da opinião pública, que foca nas atitudes e concepções de corrupção expressos pela opinião pública. Um ato é considerado corrupto na medida em que a sociedade o define como tal, sendo que a opinião pública pode variar e ser diferente da lei (BREI, 1996; GARDINER, 2002; HEIDENHEIMER, 1989).

Já na perspectiva do mercado, as teorias econômicas e as leis do mercado é que determinam se existe ou não a corrupção, sem levar em conta o impacto moral. Aqui existe a compra de favores junto aos responsáveis pelas políticas econômicas, buscando maximizar decisões (HODGKINSON, 1997; BREI, 1996; HEIDENHEIMER, 1970). Em outra perspectiva, a do cargo público, a corrupção ocorre quando titulares de cargos públicos praticam atos que desviam de normas vinculativas para fins impróprios. A corrupção seria um comportamento que se desvia dos deveres normais de um cargo público em favor de relação privadas, ganhos pecuniários ou mesmo de status para si próprio ou pessoas próximas (HEIDENHEIMER, 1970; NYE, 1967).

Pela perspectiva realista, a corrupção é definida em uma concepção da política que visualiza uma tensão entre a busca do poder e manutenção do quadro regulamentar em que a concorrência acontece. Por fim, na perspectiva histórico-cultural, a corrupção é conceituada pelas práticas tradicionais e percepções culturais difundidas pela sociedade 
ao longo do tempo, levando em consideração práticas e percepções tradicionais como base para identificar o que deve ser considerado como corrupto ou não (HODGKINSON, 1997).

Nessa última perspectiva, a compreensão do contexto cultural é especialmente importante para o entendimento do modo como a corrupção opera em um país ou região. No caso brasileiro, suas raízes culturais são formadas basicamente por um triângulo composto pelos colonizadores portugueses, pelos índios que originalmente aqui habitavam e pelos negros africanos trazidos pelo processo de escravização. Cada uma dessas culturas deixou características marcantes na formação da cultura brasileira, mas, conforme estudiosos do assunto, aquelas herdadas dos portugueses foram as que mais contribuíram para que 0 Brasil fosse o que é hoje em termos culturais (BORGES DE FREITAS, 1997; FAORO, 2001).

Para Faoro (2001), a explicação para as dificuldades enfrentadas pelo estado brasileiro está justamente no caráter de sua formação histórica, sobretudo, em seu passado colonial. A estrutura patrimonialista adquirida dos colonizadores (Estado Português), e a sua estrutura administrativa foi importada para a colônia após o descobrimento, sendo reforçada, posteriormente, na vinda da família real portuguesa para o Brasil, nos anos 1800, transformando-se em um modelo a ser seguido para a estruturação da Independência, do Império, e, posteriormente, da República no Brasil. Ou seja, o patrimonialismo se tornou uma característica marcante no desenvolvimento do estado brasileiro.

Estando Portugal situado entre a Europa e a África, sua localização geográfica propiciava contatos com vários povos e culturas diferentes, por se tratar de uma zona de trânsito. O fluxo e refluxo de diferentes povos fez com que o país não estabelecesse uma hegemonia de uma determinada etnia, ocasionando alternâncias no poder e possibilidades de grande mobilidade social. Essa ausência de uma etnia portuguesa se refletiu no Brasil, tornando-a uma nação receptível a diversas outras. Portanto, a cultura que marcou a coIonização brasileira e contribuiu para a formação de sua sociedade foi marcada por traços de flexibilidade, contrastes e antagonismos, que, de certa forma, ainda estão presentes atualmente (BORGES DE FREITAS, 1997).

A corrupção não ocorre apenas nos países do hemisfério sul, ou nas nações mais pobres. Em diferentes formas, esquemas de corrupção são engendrados em todo o mundo, desenvolvendo-se em sigilo com o apoio de uma rede de participantes, até que, por motivos variados, a transgressão venha a público, podendo se transformar em um escândalo ou não. O escândalo é definido por Adut (2005) como a publicidade perturbadora da transgressão. São acontecimentos que geram agitação política e midiática, atraindo grande atenção por um determinado período, até que começam a ser esquecidos e substituídos por novos escândalos, mesmo que não tenha chegado ao seu desfecho político e legal (SILVA, T., 2013).

Em outra abordagem, os escândalos são padrões de comunicação construídos ou selecionados socialmente. Esser e Hartung (2004) definem estes padrões como uma intensa comunicação pública a respeito de uma falha real ou imaginária, sendo essa falha condenada por consenso, atendendo a uma indignação ou revolta universal. Nesse entendimento, uma das funções do escândalo seria o controle social, atuando como uma forma de sanção a comportamentos que vão contra as normas sociais e punindo os ofensores.

O escândalo é uma espécie de grande indignação coletiva, que surge como resposta a uma transgressão de normas que se torna pública, sendo a reação do público uma 
sanção contra a transgressão praticada, revelando uma ordem moral que é temporariamente interrompida, e, consequentemente, revela as normas sociais fundamentais que compõem o tecido moral da sociedade (JACOBSSON; LÖFMARCK, 2008).

Para Chaia e Teixeira (2001), dois tipos de escândalos podem ser distinguidos: os midiáticos e os políticos. A diferença é que o escândalo político implica em lideranças políticas, envolvidas com o poder político, em um cenário também político, demonstrando o mau uso ou o abuso do poder. Apesar de a imprensa pregar um discurso de apartidarismo, a denúncia de um escândalo gera consequências partidárias e eleitorais, intencionalmente ou não, o que acaba favorecendo grupos oposicionistas. No Brasil, os principais fatos explorados pela mídia para a construção dos escândalos são a corrupção e o suborno político, que se dão através da malversação de recursos públicos, desvios de verbas, financiamentos ilícitos de campanhas, compra de votos, favorecimento em licitações e no serviço público, entre outras ações (AZEVEDO, 2010).

Os escândalos emergem como alegações ou revelações sobre comportamentos que eram desconhecidos até então, e que violam normas sociais ou legais (COBB; TAYLOR, 2015). Eles ajudam a esclarecer linhas de conduta diferentes ou conflitantes, sendo uma oportunidade para que se possa validar ou modificar as normas existentes, constituindo um momento para o esclarecimento de conflitos, posicionamento ou solidificação moral (JACOBSSON; LÖFMARCK, 2008).

Para Thompson (2000), os escândalos são lutas pelo poder simbólico que colocam a reputação e confiança em jogo, e referem-se a práticas ou fatos que implicam em transgressões variadas, e que se tornam conhecidos por outras pessoas, sendo considerados suficientemente sérios para causar uma resposta pública. Algumas características são marcantes em um escândalo (THOMPSON, 2000) como, por exemplo, o potencial de que a sua divulgação irá abalar a reputação de todos os indivíduos que estão envolvidos, podendo implicar em processos judiciais e perda de cargos. Nessa perspectiva, um escândalo só pode surgir caso um acordo tácito entre as partes envolvidas que mantêm o assunto em nível sigiloso seja quebrado, e que haja resposta pública a respeito do que for divulgado a partir disso.

Outro ponto é abordado por Cobb e Taylor (2015), ao acrescentarem que os escândalos são considerados políticos caso se refiram a comportamentos que possuem potencial para abalar a imagem e reputação de candidatos, partidos, instituições ou funcionários públicos. Os escândalos revelam a existência de uma contradição entre o ideal normativo e as práticas. Eles possuem um papel importante que vai além da simples revelação das transgressões praticadas, pois exercem uma função de teste das normas sociais, contribuindo para a sua evolução (DE BLIC; LEMIEUX, 2005).

A origem de um escândalo pode se dar a partir de acidentes ou de revelações e exposições neutras, não sendo, necessariamente, causado de forma intencional (ADUT, 2004). O surgimento do escândalo provocará um processo de discussão pública dos valores e normas, e colocará os atores em disputas para que se posicionem de modo a resolver conflitos entre ideais e práticas. 0 escândalo pode afetar a imagem, reputação e a confiança nos atores e instituições envolvidas, mas, também, pode acarretar na mudança dos valores tradicionalmente defendidos e nas práticas tradicionalmente adotadas (SILVA, T., 2013). Nesse entendimento, os escândalos políticos podem afetar todo o processo eleitoral 
e a tomada de decisão do eleitor, pois diminui a credibilidade daqueles que estão envolvidos nos escândalos. Um segundo efeito pode ter consequências duradouras na prática da democracia, provocando uma crise de legitimidade política que não pode ser atribuída exclusivamente ao escândalo, mas o ritmo e a forma da política da mídia ajudam a estimular um desânimo com o processo democrático (CASTELLS, 2007).

Para que a exposição ou alegação de uma transgressão atraia atenção e acarrete na possível reação do público, a transgressão real ou suposta deve ter sido praticada por alguém de status elevado, ou implicar pessoas ou instituições de status elevado aos olhos da sociedade. $O$ alto status de um suposto ou real criminoso político assegura que a transgressão se torne exemplar quando é revelada ao público, multiplicando os efeitos gerados pelas alegações públicas (ADUT, 2004).

Rennó (2007) identificou que os escândalos de corrupção revelados no governo Lula não foram suficientemente fortes para levar os eleitores a punir o candidato nas urnas, prevalecendo outros critérios relacionados à economia, visão geral do governo e questões partidárias. Nessa mesma linha, Florentino (2008) identificou que, dentre outros critérios como idade avançada, pertencimento a grupos políticos decadentes e bancadas pequenas, a exposição em escândalos políticos também faz com que alguns dos envolvidos desistam de uma nova disputa eleitoral.

No contexto norte-americano, Puglisi e Snyder (2011) identificaram que jornais com inclinação democrata fazem uma cobertura relativamente maior dos escândalos envolvendo políticos do partido republicano do que escândalos envolvendo políticos do partido democrata, enquanto jornais com inclinação republicana tendem a fazer o caminho inverso. Também nos Estados Unidos, Cobb e Taylor (2015) concluíram que os vários escândalos democratas não resultaram em responsabilização partidária coletiva significativa, e apesar da considerável atenção da mídia e de um esforço dos republicanos para trazer os esquemas de corrupção dos democratas à tona, menos de um terço dos eleitores conseguia se lembrar com precisão de qualquer um deles, portanto, os eleitores não poderiam punir a corrupção partidária se não tinham conhecimento suficiente a seu respeito (COBB; TAYLOR, 2015).

\section{A PESQUISA DOS REPERTÓRIOS INTERPRETATIVOS}

Este trabalho classifica-se na categoria de natureza qualitativa, em que um fenômeno pode ser mais bem compreendido se for observado no contexto em que ocorre e do qual é parte, devendo ser analisado numa perspectiva integrada (FLICK, 2009). Nosso contexto de pesquisa foi a cobertura da mídia sobre a Operação Lava-Jato, delimitado ao primeiro ano de cobertura da operação, contado a partir da data de sua deflagração. Como técnica de pesquisa, conduzimos uma pesquisa documental (FLICK, 2009) nas reportagens da revista Veja, que explicita uma tendência contrária ao governo do Partido dos Trabalhadores (PT) e a Carta Capital, que apoiou abertamente os candidatos do PT à presidência. Para análise das reportagens, utilizamos como técnica a análise temática, que consiste em "[...] um método para identificar, analisar e reportar padrões (temas) dentro de dados" (BRAUN; CLARKE, 2006, p. 6). Partimos do pressuposto de que a linguagem não é transparente e gera conhecimento a partir do próprio texto, pois entende-se que esse possui uma materialidade simbólica própria e significativa (ORLANDI, 2009). 
As práticas discursivas são o foco central de análise na abordagem construcionista, constituindo um importante caminho para a compreensão da construção de sentido em nosso cotidiano (SPINK; FREZZA, 2013). Elas são a linguagem em ação, as maneiras pelas quais as pessoas produzem sentido e se posicionam frente a situações e relações sociais cotidianas (SPINK; MEDRADO, 2013). A partir das práticas discursivas, buscamos identificar os repertórios interpretativos contidos nas produções da mídia analisada sobre 0 assunto em questão. Spink e Medrado (2013, p. 28) definem os repertórios interpretativos como "[...] as unidades de construção das práticas discursivas - o conjunto de termos, descrições, lugares-comuns e figuras de linguagem - que demarcam o rol de possibilidades de construções discursivas".

Para operacionalizar a pesquisa, nos orientamos por três questões: (1) quais repertórios interpretativos sobre corrupção são utilizados pela mídia ao reportar os casos em estudos? (2) quais perspectivas teóricas sobre corrupção surgem nos discursos da mídia? (3) as implicações dos esquemas de corrupção surgem nos discursos? Se sim, de que forma elas se manifestam? Para organizar, codificar e analisar os dados, aplicando a abordagem da análise de práticas discursivas, conforme orientam Potter e Wetherell (1987), adotamos os seguintes procedimentos: leitura do material; codificação do material; agrupamento das codificações semelhantes em unidades de significados, que são os repertórios interpretativos; interpretação e análise dos relatos para ilustrar a análise e discussão.

A pesquisa foi realizada nos acervos on-line dos sites das revistas. Levando em consideração que a operação Lava-Jato foi deflagrada em 17 de março de 2014, as primeiras edições que poderiam abordar o tema seriam as do dia 26 de março de 2014 , que foram as primeiras a serem fechadas após a deflagração da operação. Diante disso, nosso período de análise foi de 26 de março de 2014 a 26 de março de 2015.

Utilizamos o mecanismo de buscas disponível nos sites de cada uma das revistas, buscando pelo termo "Lava-Jato". Reportagens que traziam apenas entrevistas, mensagens do leitor, e colunas com pequeno conteúdo como "Panorama", da revista Veja, e "A Semana", da revista Carta Capital foram desconsiderados, bem como aquelas que citaram o termo "Lava-Jato", mas que em seu conteúdo não traziam a temática da operação.

As unidades de análise constituem-se de cada período contido nos parágrafos das reportagens. Após a leitura de cada período, as informações relevantes referentes à operação Lava-Jato foram codificadas e catalogadas, de acordo com a reportagem à qual se referiam e, também, à página da reportagem, possibilitando a volta ao texto de onde fora extraída a informação, caso necessário. A partir das unidades de análise, extraímos os repertórios mais utilizados pela mídia analisada na construção do escândalo de corrupção.

\section{REPERTÓRIOS INTERPRETATIVOS NA CONSTRUÇÃO E DESCONSTRUÇÃO DO ESCÂNDALO}

Inicialmente, realizamos um mapeamento da cobertura das duas revistas, o que não evidenciou distanciamento significativo, em termos quantitativos. 0 material empírico resultou em 59 reportagens da revista Veja, que continham no total 252 páginas, entre textos e imagens, e em 55 reportagens da revista Carta Capital que, somadas, continham 177 
páginas, também entre textos e imagens. No total foram lidas e analisadas 114 reportagens de ambas as revistas, em um total de 429 páginas, entre textos e imagens.

Após a leitura do material coletado, descartamos algumas reportagens da análise pelo fato de que, apesar de mencionarem o termo de busca "Lava-Jato", não se referiam a fatos ligados diretamente à operação, restando 56 reportagens da revista Veja e 52 da Carta Capital.

Identificamos que, até o mês setembro de 2014, não houve um número significativo de reportagens sobre a operação Lava-Jato, principalmente, na revista Carta Capital. Vale ressaltar que, entre junho e julho de 2014, o Brasil sediou a copa do mundo de futebol masculino, evento que atraiu a atenção da mídia em geral, o que pode ter deixado a operação em segundo plano. Além disso, no ano de 2014, ocorreram as eleições presidenciais, o que também atraiu maior atenção dos editoriais.

Os componentes que formam o escândalo foram identificados nas reportagens analisadas de ambas as revistas. Para que ocorra um escândalo, a primeira coisa que deve acontecer é a transgressão de valores ou normas sociais (SILVA, T., 2013). No escândalo da operação Lava-Jato produzido pela mídia analisada, são diversos os exemplos de transgressões praticadas por políticos, funcionários da empresa e executivos de empreiteiras envolvidas no esquema.

Em conluio com funcionários da estatal, um grupo que reúne as maiores empreiteiras do país superfaturava seus serviços e repassava dinheiro desviado aos partidos aliados do governo - PT, PMDB e PP (HISAYASU; RANGEL, 2015, p. 50).

Não existe escândalo caso a transgressão ocorrida não fique conhecida pelo público. Após o ato de transgressão (real ou suposta) para que se caracterize o escândalo deve ocorrer a publicização da transgressão, que pode se dar através de revelações por diversos atores sociais, como indivíduos, coletivos e a mídia (SILVA, T., 2013). No escândalo da Lava-Jato, a publicização das transgressões ocorreu, principalmente, através de depoimentos prestados nos acordos de delação premiada feitos pelos funcionários da Petrobras, executivos de empreiteiras e doleiros envolvidos no esquema. A partir das delações e outras fontes de informações, as mídias analisadas tornavam públicos os fatos relacionados à investigação da operação: "Já nos primeiros depoimentos, ele (Paulo Roberto Costa) confirmou a parceria com grandes empreiteiras para arrecadar propina e citou como beneficiários um ministro, três governadores, seis senadores e pelo menos 25 deputados federais [...]" (GASPAR; RANGEL, 2014, p. 72).

Após os fatos do escândalo se tornarem conhecidos, os públicos interessados ou identificados com as normas e valores que foram transgredidos reagem negativamente à transgressão denunciada (SILVA, T., 2013). Na cobertura do primeiro ano da operação Lava-Jato pelas mídias analisadas, as principais reações identificadas foram as manifestações públicas ocorridas nas ruas, em protestos contra o governo e a corrupção, e também através do que ficou conhecido como "panelaço", em que, nos momentos de pronunciamento da presidenta Dilma Rousseff em rede nacional, parte da população fazia barulho batendo 
panelas nas janelas de casas e apartamentos. Também aconteceram protestos por parte de operários de empresas atingidas pelo esquema.

\begin{abstract}
Irritados com a interrupção do programa, os telespectadores, sobretudo aqueles dos bairros que se declaram nobres, erguem-se do sofá da sala, de panela em punho, vão à janela, debruçam-se a meio busto e batem o instrumento improvisado com talheres adequados à tarefa e com o vigor dos tocadores de tambor de gasolina na Martinica. Acompanha o batuque clangoroso o coro "Fora Dilma", com o contorno dos melhores exemplos do primitivo turpilóquio nacional (CARTA, M., 2015, p. 14).
\end{abstract}

Por fim, tem-se as consequências causadas pelo escândalo, que podem ser tanto sobre as pessoas quanto sobre as instituições envolvidas na transgressão, e podem ser na forma de processos criminais, perda de cargos, prejuízos à imagem pública e a confiança, dentre outras formas (SILVA, T., 2013). No primeiro ano da operação Lava-Jato, as reportagens já trazem diversas consequências para os envolvidos no esquema, como a prisão e indiciamento de alguns funcionários da Petrobras e executivos de empreiteiras, e também consequências negativas para a própria Petrobras, como queda na cotação das ações da empresa e no seu valor de mercado, além de corte em investimentos por conta das perdas causadas pelos desvios praticados: "No final os 88,6 bilhões foram para o balanço apenas como informação complementar. Mesmo assim, provocaram um terremoto político que, além de levar à saída de Graça e sua equipe, derrubou as ações" (GASPAR, 2015, p. 54).

Como analisamos apenas o primeiro ano de cobertura midiática da operação após a sua deflagração, encontramos diversas consequências que são mencionadas nas reportagens das revistas que não chegaram a serem concretizadas durante o período de análise. Como exemplos, podemos citar o impeachment da presidenta Dilma Rousseff, que não teve como motivo revelações da Lava-Jato em si, mas que foi influenciado pela operação, assim como a cassação do mandato e prisão do ex-presidente da Câmara dos deputados, Eduardo Cunha.

\title{
4.1 A CONSTRUÇ̃̃O DO ESCÂNDALO POLITIICO PELAS REVISTAS VEJA E CARTA CAPITAL E SEUS REPERTÓRIOS INTERPRETATIVOS
}

Iniciamos apresentando três repertórios interpretativos mais significativos identificados na Revista Veja.

\section{1: A Lava-Jato é um "Petrolão"}

O repertório mais presente nas reportagens é de que o escândalo descoberto na operação Lava-Jato se trata de um "Petrolão", ou seja, um novo caso com características semelhantes ao Mensalão ocorrido entre 2005 e 2006 no governo Lula, no entanto, que agora ocorre dentro da maior estatal brasileira, a Petrobras. A junção do nome da Petrobras, alvo central do esquema de corrupção investigado na Lava-Jato, com o Mensalão, deu origem ao "Petrolão". 
Além de "Petrolão", a Veja utiliza, com menos recorrência, o nome "Propinoduto" para se referir à operação, em alusão ao ramo de atividade da Petrobras, que utiliza dutos para escoamento da produção de petróleo e gás. O "Propinoduto" seria, então, os caminhos por onde escoa a propina que era cobrada pelos políticos e funcionários da Estatal nos contratos com as empreiteiras. Não podemos afirmar que foi o editorial da revista Veja que criou esses apelidos para a Lava-Jato, porém esses estão marcados nas reportagens da revista, e foram facilmente assimilados pelos leitores da revista e pela mídia em geral.

O uso do termo "Petrolão" faz com que a revista busque aproximar a operação Lava-Jato do escândalo do mensalão, reforçando a sua posição de que o PT é o principal responsável pela corrupção dentro da Petrobras, uma vez que o mensalão teve o PT como principal partido envolvido, e suas investigações levaram a consequências, como a prisão de vários líderes do partido. Em uma das reportagens, inclusive, a revista faz uma comparação entre os ex-presidentes Lula e Dilma, afirmando que o primeiro teve o mensalão em seu governo, e a segunda o "Petrolão". A revista também afirma que as investigações do mensalão foram frutos de uma denúncia publicada por ela.

Como lembra a Carta ao leitor desta edição de VEJA, as agruras do PT com o petrolão são fruto do mesmo pecado original que produziu o escândalo do mensalão: a ideia assombrosa de que o partido pode se servir do Estado como se fosse sua propriedade, das leis como se existissem apenas para os outros e das instituições como bombeiros de suas eternas crises (SAKATE, 2014, p. 47) [grifos nossos].

As investigações do petrolão desnudam novos propinodutos a cada dia, o endividamento é preocupante e a situação interna é de descontentamento (GASPAR, 2015, p. 52) [grifos nossos].

Apenas a título de comparação, em todas as reportagens analisadas da revista Carta Capital, apenas uma vez o termo "Petrolão" foi mencionado, em uma situação em que a reportagem afirmava que os advogados dos empreiteiros queriam caracterizar a Lava-Jato como um esquema parecido com o Mensalão, buscando aliviar as penas de seus clientes. Justamente o que identificamos que a revista Veja faz.

\section{2: O PT criou o esquema de corrupção na Petrobras}

Outro repertório que fica claro a partir da análise das reportagens é o posicionamento da revista Veja de que o PT foi o mentor do esquema de corrupção, além de ter sido o maior beneficiado, apesar do envolvimento de outras siglas partidárias. Para a revista Veja, os partidos envolvidos no escândalo dentro da Petrobras seriam, além do PT, dois de seus principais aliados, o PMDB e o PP, ficando clara a posição da revista como oposição ao governo do partido. Ao enfatizar que o PT foi quem criou o esquema de corrupção na Petrobras, a revista Veja não menciona (intencionalmente ou não) outros escândalos de corrupção que ocorreram nos governos anteriores ao governo do PT, relacionados a outros partidos políticos, fazendo com que estes caiam no esquecimento de seus leitores.

Segundo relatos, o PT não só é apresentado como responsável pela montagem e pela operação do esquema de corrupção na estatal como também se nutriu 
dele. E ainda mais grave: dinheiro da corrupção pode inclusive ter ajudado a eleger Dilma Rousseff (BONIN; HISAYASU, 2014, p. 64).

Outro aspecto encontrado nas reportagens, principalmente após o mês de outubro de 2014, é que, para a revista Veja, o ex-presidente Lula e a presidenta à época da deflagração da operação, Dilma Rousseff, sabiam de todo o esquema de corrupção que se dava dentro da maior empresa estatal do país, a Petrobras. Para o semanário, além de Lula e Dilma serem coniventes com o esquema de corrupção, os dois também teriam se beneficiado com o dinheiro desviado da estatal através dos contratos fraudulentos e estariam no topo da cadeia de comando do esquema. A revista Veja, inclusive, dedicou ao tema uma capa de revista da edição 2397, de 29 de outubro de 2014, trazendo trechos vazados da delação premiada do doleiro Alberto Youssef, em que ele afirmara que a alta cúpula do governo federal tinha conhecimento do esquema. Como estávamos em pleno segundo turno da disputa presidencial, a revista antecipou a circulação da edição para que essa chegasse às bancas e nas casas dos assinantes antes do pleito, de modo a influenciar o leitor eleitor.

O doleiro já afirmou que o ex-presidente Lula e a presidente Dilma Rousseff sabiam da existência da quadrilha na Petrobras. As novas declarações indicam que, além de saberem, eles podem ter se beneficiado política e eleitoralmente do esquema (BONIN; HISAYASU, 2014, p. 68).

Uma ideia que é reforçada nas reportagens da Veja é a vinculação da imagem do ex-presidente Lula com o PT. Em várias reportagens, quando o partido é citado, a citação vem acompanhada de informações como "PT de Lula", reforçando o posicionamento da revista em oposição aos governos do ex-presidente e em oposição ao atual governo do mesmo partido. Vale ressaltar que, em nenhuma das reportagens analisadas, vinculação semelhante foi feita entre outros partidos e seus líderes: "Seguindo o dinheiro, os investigadores da Lava-Jato chegaram a Pedro Barusco, gerente da Petrobras, que disse ter entregue 200 milhões de dólares em propinas ao tesoureiro Vaccari e ao PT de Lula" (BONIN, 2015, p. 55).

\section{3: A Lava-Jato é o maior esquema de corrupção da história do país}

O terceiro repertório identificado nas reportagens da revista Veja, na construção do escândalo, foi a alcunha de que o caso de corrupção descoberto pela investigação da operação Lava-Jato é maior esquema de corrupção da história do país. A revista frisa esse rótulo em grande parte das suas reportagens, fixando esta ideia na cabeça dos leitores. Porém, valores comparativos de outras operações não confirmam que esse seja o maior esquema de corrupção. Além disso, há de se considerar que outros esquemas de corrupção estejam em curso e ainda não vieram a público. Segundo a revista, o que ocorreu foi um grande assalto aos cofres da Petrobras, causando prejuízos incalculáveis para a Estatal, e enriquecendo corruptos e corruptores.

O esquema, que segundo a revista revelou uma quadrilha que cometeu um grande assalto aos cofres da maior empresa estatal brasileira, teria causado prejuízos incalculáveis para a Petrobras, e levou à prisão de empresários das maiores empreiteiras do país. A operação seria mais uma oportunidade para o país fazer uma limpeza na corrupção instaurada 
em suas instituições, levando corruptos e corruptores a cumprirem penas nunca impostas para este tipo de crime.

O escândalo de corrupção na Petrobras já é, de longe, o maior de todos os tempos. Calcula-se que pelo menos 4 bilhões de reais foram desviados por diretores nomeados por indicação política na estatal, valendo-se de propinas cobradas de grandes empreiteiras e operadas por doleiros (RANGEL, 2015, p. 48).

Nas reportagens analisadas evidencia-se uma organização criminosa e cada partido envolvido no esquema tinha um ou mais operadores responsáveis pela movimentação da parte de cada legenda. A revista mostra que o esquema de corrupção era tão bem organizado que criou um sistema inovador de entrega de propina em domicílio, o que foi chamado pela revista Veja de "money delivery", ou "propina delivery". Funcionários de Alberto Youssef faziam entregas de dinheiro em espécie em todo o país, carregando os valores em malas até os seus destinos. Segundo a revista, o serviço inovador do "Petrolão" atendia clientes especiais da "quadrilha" que teria desviado bilhões da Petrobras na última década: "[...] "money delivery" do "Petrolão", um serviço inovador em matéria de corrupção criado pelo doleiro Alberto Youssef para agradar a "clientes especiais" da quadrilha que desviou bilhões da Petrobras" (BONIN, 2014, p. 48).

A seguir, apresentamos os três repertórios interpretativos mais significativos identificados na revista Carta Capital.

\section{1: A Lava-Jato é um recurso político-eleitoral}

O primeiro repertório identificado é uma crítica ao uso político-eleitoral da operação. A revista Carta Capital se posiciona contra a utilização do escândalo com fins políticos, e esse posicionamento é reforçado pelo fato de que, no período pré-eleitoral, poucas reportagens foram veiculadas a respeito das investigações e demais desdobramentos da operação Lava-Jato. Desde a deflagração da operação, em março de 2014, até o mês de outubro de 2014, quando aconteceram os dois turnos das eleições, apenas seis reportagens foram encontradas em nossa busca, sendo duas no mês de abril, voltando a abordar o tema somente em setembro com uma reportagem, e outras três reportagens no mês de outubro de 2014. Entendemos que essa ausência de destaque da Lava-Jato por parte da Carta Capital seja decorrente de seu posicionamento ideológico a favor do PT, que estava no governo federal durante o período analisado.

A revista traz relatos de que investigadores e Ministério Público Federal também demonstravam preocupação com a exploração da operação para esses fins. Para a revista, a utilização do escândalo, tanto por parte da mídia quanto dos próprios partidos e seus membros, com o objetivo de denegrir a imagem de candidatos ou partidos como um todo, através da criação de boatos e divulgação de informações inverídicas, além de prejudicar o processo eleitoral também afeta o bom andamento das investigações, além de ameaçar a oportunidade de se desmontar todo o esquema. 
poder. Foi assim nas duas disputas anteriores, não é diferente agora. No início do segundo turno, o escândalo da Petrobras voltou com força ao noticiário (SERAPIÃO, 2014a, p. 28).

A antecipação da circulação da revista Veja, às vésperas do segundo turno das eleições presidenciais de 2014, inclusive, foi criticada pela revista Carta Capital, que afirmou que tal vazamento poderia prejudicar o processo de colaboração do doleiro com a justiça. $A$ crítica da revista Carta Capital vai além, pois, segundo a reportagem, o advogado do doleiro teria negado tal conteúdo veiculado pela revista Veja, criticando também a implantação de notícias na mídia para tumultuar os processos.

Os investigadores tentam proteger a Lava-Jato dos efeitos deletérios do uso eleitoral do escândalo. [ [...] Um bom exemplo das dificuldades a ser enfrentadas pela Lava-Jato é a repercussão da última armação da revista Veja. Três dias antes do segundo turno, a semanal sustentou, com base na suposta delação, que a então candidata Dilma Rousseff e o ex-presidente Lula "sabiam de tudo" sobre os desvios praticados pela trupe de Youssef na Petrobras. Com o alarde necessário para chamar atenção do eleitorado, a revista do Grupo Abril antecipou em dois dias sua circulação para revelar os supostos detalhes da conivência do ex-presidente e da atual mandatária. Repercutida à exaustão, a reportagem conseguiu tumultuar a relação entre as autoridades envolvidas no caso e pode atrapalhar o processo de colaboração do doleiro preso (SERAPIÃO, 2014b, p. 36).

Em contrapartida, a revista Veja não menciona diretamente se é contra ou a favor, mas afirma na reportagem veiculada às vésperas da eleição, na edição que teve a sua circulação antecipada, que era dever jornalístico da revista publicar esses fatos às vésperas da eleição presidencial, e que a revista não faz a publicação visando aumentar as chances de determinado candidato em detrimento de outro, mas, sim, ampliar o grau de informação de seu leitor sobre fatos relevantes que não escolhem hora nem momento para acontecer. Se compararmos o período da deflagração da operação até o mês de outubro de 2014, quando ocorreram os dois turnos das eleições presidenciais, o número de reportagens veiculadas pela Veja sobre a Lava-Jato foram o triplo da revista Carta Capital, sendo uma delas a reportagem citada anteriormente. A partir desse fato, entendemos que a revista Veja buscou influenciar o seu público no processo eleitoral, a partir do seu papel de oposicionista.

\section{2: A corrupção não é exclusiva do PT ou de outro partido}

Um segundo repertório recorrente nas reportagens de Carta Capital é de que a corrupção não é uma criação do PT, bem como não é exclusiva desse ou daquele partido. $\mathrm{Na}$ visão do editorial da revista, a corrupção é um mal antigo e crônico que assola o Brasil há tempos, com diversas consequências para a sociedade brasileira, e não uma criação recente a partir do governo Lula.

Apesar de reconhecer que os principais partidos envolvidos no esquema descoberto seriam os já citados PT, PMDB e PP, a revista menciona que outros partidos fizeram parte e foram beneficiados pelos desvios na Petrobras e, inclusive, tiveram campanhas financiadas com dinheiro de propina. Partidos como o DEM, o PTB e o PSDB também teriam sido finan- 
ciados pelo dinheiro da corrupção. Ademais, em alguns momentos, a revista Carta Capital sai em defesa do governo PT, apontando números positivos conquistados, e que o PT, Lula e Dilma não seriam os únicos responsáveis pela crise: "Os desdobramentos da Lava-Jato mostram que nenhum partido político está imune ao desenrolar das investigações, embora o trio PT-PMDB-PP seja o protagonista da trama" (SERAPIÃO, 2014c, p. 27).

Mesmo reconhecendo que a operação Lava-Jato teve sua origem nos partidos da base do governo (PT, PMDB e PP), a revista Carta Capital, em várias reportagens, amplia o foco da narrativa para outros partidos, principalmente para o principal partido de oposição ao governo Dilma, e derrotado nas últimas eleições presidenciais, o PSDB, de Aécio Neves. Os partidos da oposição, dentre eles o PSDB, também teriam sido beneficiados pelo esquema de corrupção dentro da Petrobras, inclusive, com financiamento de campanhas por parte das empreiteiras envolvidas, além de serem citados em outros escândalos anteriores à Lava-Jato. Para a revista, a oposição teria medo de ver outros escândalos passados voltarem à tona com a Lava-Jato, e que novas investigações pudessem descobrir fatos que não teriam sido revelados anteriormente, e por este motivo tentam vincular a operação à base governista: "[...] os desdobramentos das investigações em Curitiba podem reavivar ao menos quatro escândalos dos 20 anos de PSDB no Palácio dos Bandeirantes" (SERAPIÃO, 2015b, p. 31).

\section{3: A mídia nativa está a serviço dos grandes grupos de poder}

No terceiro repertório que fica claro no discurso da revista Carta Capital é o rompimento do editorial com a mídia tradicional, que é chamada de mídia "nativa", a qual, segundo as reportagens, está a serviço dos grandes grupos de poder, também chamada pela revista de "casa grande". A ação dessas mídias se daria através de um pensamento antipolítico, levando ignorância e despolitizando o seu público. Alguns grandes e tradicionais veículos de comunicação são criticados, como a revista Veja do Grupo Abril, a Globo e a Folha.

Parte dessa mídia tenta passar a ideia de que a declamada operação Lava-Jato seria fruto único e exclusivamente produzido pelo Partido dos Trabalhadores, o ex-presidente Lula e a ex-presidenta Dilma, o que, na visão do editorial, não é verdade, pois a corrupção no Brasil é um mal antigo e crônico, e não fruto de uma ou outra determinada legenda partidária e seus membros. Grandes veículos de comunicação são criticados pelos editoriais, como, por exemplo, a rede Globo e a revista Veja.

Caso consiga evitar o caminho seguido pelas outras investigações, Sergio Moro e os integrantes da Lava-Jato entrarão para a história não só por punir os que roubam há anos o País, mas também por vencer a nossa mídia nativa sempre disposta a ficar do lado da casa-grande e seus construtores (SERAPIÃO, 2015a, p. 45).

Esse tipo de mídia, inclusive, ajudaria na construção da imagem de que o PT seria o único responsável pelo escândalo de corrupção na Petrobras, o que é contestado pela revista como mostramos no repertório anterior. A partir desse posicionamento, foi possível inferir que, na visão da revista Carta Capital, a revista Veja faz parte do que eles chamam de "mídia nativa", que estaria a favor dos interesses dos grupos de poder e de quem os sustenta: "No Brasil, um pensamento antipolítico leva ao fortalecimento da casa-grande 
e incentiva a mídia nativa no seu esforço de despolitização de quantos a leem ou ouvem" (CARTA, M., 2014, p. 16).

Os repertórios interpretativos identificados nesta seção representam o posicionamento de cada uma das revistas frente à construção do escândalo de corrupção descoberto pela operação Lava-Jato. Como vimos em nosso referencial teórico, Chaia e Teixeira (2001) afirmam que o escândalo político se diferencia do escândalo midiático pelo seu campo de discussão, visto que implica em lideranças políticas que estão envolvidas com o poder político, em um cenário que também é político. Assim, os escândalos políticos podem envolver questões financeiras, corrupção e escândalos de poder, relacionados ao mau uso ou abuso de poder, o que pudemos identificar através dos repertórios interpretativos que emergiram do material analisado.

A partir da identificação dos repertórios das duas revistas analisadas, entendemos que os repertórios da revista Veja foram utilizados como uma forma de oposição ao partido da situação no governo federal, o PT, enquanto os repertórios da revista Carta Capital enfatizam que a corrupção não é exclusiva de um partido apenas, mas um mal geral, e que cabe à mídia apenas informar o leitor, e não tentar influenciá-lo a favor ou conta algum partido. Assim, interpretamos que a Carta Capital assume uma clara oposição à construção do escândalo, ou seja, uma tentativa de desconstrução do escândalo.

\section{DISCUSSÃO: A CONSTRUÇÃO E DESCONSTRUÇÃO DO ESCÂNDALO DE CORRUPÇÃO E SUAS IMPLICAÇÕES PARA A GESTÃO}

A partir da análise dos repertórios interpretativos encontrados nas reportagens analisadas das revistas Veja e Carta Capital acerca do escândalo de corrupção na Petrobras, investigado pela operação Lava-Jato, encontramos as diversas perspectivas teóricas sobre a corrupção, que foram revisadas em nosso referencial teórico, bem como os componentes de um escândalo.

A perspectiva mais recorrente sobre a corrupção encontrada nas reportagens das revistas sobre a operação Lava-Jato é a perspectiva legal, que caracteriza a corrupção como um ato que é proibido pela lei, ou seja, a transgressão de leis ou normas, e comportamentos que desviam das leis ou regulamentações (HODGKINSON, 1997; BREI, 1996; GARDINER, 2002). A corrupção seria o abuso da coisa pública em benefício privado. Exatamente o que aconteceu na Petrobras, em que os corruptos e corruptores se apropriaram da estrutura da empresa, visando benefícios próprios, de seus partidos e empresas, em detrimento dos objetivos da estatal.

A Polícia Federal descobriu que Paulo Roberto, um doleiro, políticos e prestadores de serviços estão interligados em um consórcio montado para fraudar contratos na Petrobras, enriquecer seus membros e financiar partidos políticos (MARQUES; RANGEL, 2014, p. 68).

Durante três anos, Meire manuseou notas fiscais frias, assinou contratos inexistentes, montou empresas de fachada, organizou planilhas de pagamento. Ela deu ares de legalidade a um dos esquemas de corrupção mais grandiosos desde o mensalão (BONIN, 2014, p. 55). 
Além do doleiro Alberto Youssef e apaniguados, que operavam o braço financeiro, e de Paulo Roberto Costa, ex-diretor da estatal, foram denunciados alguns dos principais executivos de seis empreiteiras. São 22 diretores das construtoras Camargo Correa, UTC Engenharia, OAS, Mendes Júnior, Engevix e Galvão Engenharia, acusados pelos crimes de corrupção ativa, lavagem de dinheiro e formação de quadrilha (SAKATE, 2014, p. 24).

Com o auxílio das delações e à luz de vultuosos prejuízos financeiros enfrentados pela Petrobras, foram investigados crimes de lavagem de dinheiro, evasão de divisas e formação de organização criminosa (MAIEROVITCH, 2014, p. 14).

A perspectiva do interesse público também está presente nas reportagens. Nessa perspectiva, baseado nos autores Hodgkinson (1997), Brei (1996), Gardiner (2002) e Heidenheimer (1970), algo é considerado correto na medida em que cumpre a finalidade para a qual foi criado, sendo a corrupção a traição ou um ato prejudicial ao interesse público para obtenção de ganho privado. Aqui o interesse público é baseado na ética e na moral. É possível identificar na operação Lava-Jato que a prevalência do interesse público foi afetada, uma vez que o sucesso da empresa é de interesse público, já que seu maior acionista é a União, e seus lucros poderiam ser investidos em prol da população.

Pena que o objetivo de tanta eficiência seja o enriquecimento pessoal pela subtração de dinheiro público que poderia ser usado para tratar pacientes do SUS, melhorar as condições dos sofridos hospitais públicos ou aumentar a oferta de leitos. Em vez disso, o vice-presidente da Câmara dos Deputados, "muito influente no partido", cuida de encher o próprio bolso e o do doleiro preso pela Polícia Federal (BONIN, 2014, p. 58).

A luta entre Moro e as bancadas criminalistas representa a disputa do interesse público contra uma elite empresarial acostumada às benesses do poder conquistadas por meio do pagamento de propinas (SERAPIÃO, 2014c, p. 27).

A perspectiva da opinião pública foca nas concepções de corrupção definidas pela opinião dos cidadãos. Para Brei (1996), o suborno é uma técnica bastante utilizada, o que também ficou caracterizado na Lava-Jato. Gardiner (2002) afirma, nessa perspectiva, que se existem diferenças significativas entre as leis e como a maior parte dos cidadãos define a corrupção, há uma tendência de que funcionários do governo sejam guiados mais pela cultura local do que pelas leis, fato que acontece com a classe política brasileira, pois como mostraram as reportagens sobre a operação Lava-Jato, existe uma cultura de impunidade para os políticos corruptos, o que traz o pensamento de que o crime compensa.

A nova etapa da investigação mira a parte intermediária do esquema, os destinatários dos subornos, os alvos ensaboados que, por tradição, são quase sempre bem-sucedidos na arte de driblar a lei. Pegue-se o caso do ex-ministro José Dirceu. Ele foi condenado à sete anos e onze meses de prisão por liderar os petistas envolvidos no escândalo do mensalão, ficou preso 354 dias, ganhou o direito de cumprir o resto da pena em casa e o privilégio de continuar desfrutando os milhões de dólares e reais que faturou em suas múltiplas consultorias. Dirceu era o exemplo de como uma punição branda desperta 
a sensação de que o crime, para alguns, realmente compensa (HISAYASU; RANGEL, 2015, p. 50).

Outra perspectiva presente nas reportagens é a centrada no mercado, em que as teorias econômicas e leis do mercado determinam se existe a corrupção. Aqui temos características como a compra de favores junto aos responsáveis pelas políticas econômicas. A corrupção seria a ação de indivíduos ou grupos no intuito de influenciar as ações da burocracia e a implementação de políticas, ou a participação anormal de grupos de interesse em processos de tomada de decisão (HODGKINSON, 1997; BREI, 1996; HEIDENHEIMER, 1970). A Petrobras, segundo a revista Veja, teria sido utilizada como instrumento de política econômica do governo, o que teria prejudicado o desempenho da empresa e pode ter contribuído para o escândalo ocorrido.

Mas abusaram do aparelhamento político da Petrobras, transformando-a em uma fonte de escândalos de corrupção. A Petrobras foi feita de ferramenta para tentar corrigir erros absurdos de política econômica, sendo obrigada a amargar prejuízos bilionários para segurar os preços do diesel e da gasolina nas bombas e, assim, mascarar a inflação. 0 resultado é desastroso para a empresa e para o Brasil (A MARCA [...], 2014, p. 53).

Costa deixou a estatal em 2012, mas as empreiteiras continuaram agradecidas, não se sabe se por serviços prestados no passado ou pela expectativa de que ele traficaria influência para favorecer os clientes no presente e no futuro ou se por uma combinação das duas atividades (BARROCAL; SERAPIÃO, 2014, p. 23).

Titulares de cargos públicos praticando atos de desvios de normas para fins impróprios. Isto é o que caracteriza a perspectiva do cargo público (NYE, 1967; HEIDENHEIMER, 1970), em que a corrupção seria resultado de abuso de autoridade que leve a ganho pessoal (não necessariamente monetário) do titular do cargo ou pessoas próximas a ele. Essa perspectiva está fortemente presente nas reportagens analisadas, uma vez que políticos e funcionários da Petrobras utilizaram a empresa para criar um esquema de corrupção que levou ao enriquecimento dos participantes, além de também financiarem os seus respectivos partidos e campanhas.

Sem a pressão das urnas, o ex-vice-presidente da Câmara já ouviu de alguns membros do conselho que sua punição será branda, no máximo uma advertência pelo "mau comportamento". Afinal, ele não é o único que tem amizade com criminosos, não é o único que usa jatos emprestados de empresários, não é o único que se aproveita do cargo para encher os bolsos de dinheiro viabilizando negócios escusos no governo (BONIN, 2014, p. 63).

É inadmissível usar o cargo para represálias contra os investigadores da Lava-Jato, como ameaçam Calheiros e Cunha (MAIEROVITCH, 2015, p. 17).

A corrupção também pode ser caracterizada por práticas tradicionais e percepções culturais que são difundidas pela sociedade historicamente ao longo do tempo, como aborda a perspectiva histórico-cultural (HODGKINSON, 1997). A ênfase na história como fator 
determinante para as atitudes das pessoas nos leva a considerar a corrupção como natureza da sociedade.

Nas reportagens identificamos que a formação do Estado Brasileiro, com base no patrimonialismo, contribuiu para a inserção de uma cultura de corrupção na sociedade brasileira, reforçada por uma cultura de impunidade, principalmente em crimes de colarinho branco cometidos por políticos e pessoas de grupos de poder influentes na sociedade. Isto confirma o pensamento de Faoro (2001) de que a explicação para as grandes dificuldades enfrentadas pelo Estado brasileiro está justamente no caráter de sua formação histórica, principalmente, na estrutura patrimonialista adquirida dos colonizadores.

O que afirmamos no parágrafo anterior também vai ao encontro da teoria da cultura política, em que os padrões culturais agem de forma a viabilizar (ou inviabilizar) os comportamentos corruptos (GOMES, 2010), e à forma de corrupção cultural abordada por Filgueiras (2006), em que a desonestidade e os costumes fazem com que os agentes reproduzam práticas que colocam em risco a integridade e a ordem da comunidade.

Num país habituado à impunidade, cujos políticos têm horror atávico a assumir seus erros e uma propensão irrefreável a atribuí-los a terceiros, pode ser difícil acreditar em normalidade institucional [ [...]]. (PETRY, 2015, p. 59)

Trambiques, falcatruas, o patrimonialismo inesgotável no País que às vezes se arvorou a ser do futuro, terra de 500 anos de predação e onde a escravidão, oficialmente encerrada depois de três séculos e meio, ainda não terminou na prática do cotidiano (CARTA, 2015, p. 14).

Respondendo ao objetivo geral da pesquisa, identificamos, na revista Veja, primeiramente, o repertório que busca aproximar o escândalo da Petrobras com o escândalo do mensalão, tratando assim o escândalo pelo termo "Petrolão". Esta caracterização do escândalo pela revista evidencia a sua posição de que o governo PT foi o principal responsável pelo escândalo dentro da estatal, uma vez que este mesmo partido foi quem orquestrou o mensalão. Um segundo repertório da revista Veja é que o PT foi o mentor do esquema e o maior beneficiado com o dinheiro desviado, reforçando o posicionamento oposicionista da revista. E por fim temos o repertório de que, para a revista Veja, o escândalo investigado pela operação Lava-Jato é o maior esquema de corrupção da história do nosso país.

Já para a revista Carta Capital, o primeiro repertório interpretativo utilizado pelo seu editorial é a crítica ao uso político-eleitoral da operação, pois isto poderia vir a prejudicar o andamento das investigações. A revista ainda faz uma crítica a antecipação de veiculação de uma edição da revista Veja nas vésperas do segundo turno, no intuito de influenciar o eleitorado contra o PT. Fato é que o escândalo de corrupção divulgado pela mídia no ano eleitoral não foi capaz de afetar o resultado nas urnas, visto que a candidata do partido da situação à reeleição saiu vitoriosa das eleições. Este resultado corrobora o estudo de Rennó (2007), que identificou que os escândalos revelados no governo Lula não foram suficientes para punir o candidato nas urnas, que também foi reeleito em 2006, prevalecendo outros fatores como economia e questões partidárias.

O segundo repertório identificado na revista Carta Capital é de que a corrupção é um mal antigo e crônico em nosso país, não sendo criação nem exclusividade do PT ou de 
qualquer outro partido. E o terceiro repertório encontrado mostra um rompimento da revista Carta Capital com a mídia tradicional, chamada de mídia nativa, que segundo as reportagens analisadas estaria a favor dos grandes grupos de poder. Neste repertório identificamos críticas a grandes grupos de comunicação do país, como a própria revista Veja do grupo Abril, que faria parte da mídia nativa citada pela revista.

Os repertórios interpretativos identificados foram produzidos em um contexto socioeconômico e político influenciado pela formação do Estado Brasileiro e as suas raízes culturais, as quais estão diretamente ligadas aos problemas enfrentados atualmente, dentre eles, a corrupção institucionalizada no país. O contexto em que se deu o primeiro ano da operação Lava-Jato foi coberto de outros acontecimentos relevantes no país. Primeiramente, menos de três meses após a deflagração da operação, foi realizado no Brasil um dos maiores eventos esportivos do planeta, que é a Copa do Mundo de Futebol. A cobertura da realização desse evento teve grande destaque na mídia a nível nacional e mundial, o que influencia na cobertura de outros acontecimentos, como a própria operação Lava-Jato.

Para os veículos analisados nesta pesquisa, a corrupção está diretamente relacionada com as nossas raízes históricas. A noção de que o Estado estaria voltado para satisfazer os interesses dos próprios dirigentes como um bem em si próprio, herança do patrimonialismo, com o tratamento da coisa pública pelo governante como se privada fosse, faz com que interesses privados prevaleçam sobre os interesses da coletividade (FAORO, 2001). Esta sobreposição do interesse particular em detrimento do interesse coletivo fica clara no escândalo de corrupção analisado, uma vez que os desvios de dinheiro público visavam o enriquecimento próprio dos membros vinculados ao esquema e de suas organizações, sejam empresas ou partidos políticos.

A atuação da mídia, através da publicização, é que torna visíveis aquelas atividades que estavam escondidas do grande público, criando um campo complexo entre as imagens e informações, o que torna difícil o controle da visibilidade midiática e a transforma em uma armadilha para as lideranças. 0 surgimento do escândalo midiático/político se relaciona com as transformações sociais que acontecem no mundo moderno, que redefinem as relações entre a vida pública e a privada, através de novas formas de visibilidade e publicização que emergem e provocam novas relações entre o escândalo e a mídia, como afirmaram Chaia e Teixeira (2001). Assim, os repertórios utilizados pelas revistas na construção dos escândalos contribuem para a construção das representações acerca do esquema de corrupção da operação Lava-Jato.

A comunicação, como um vetor de transmissão da linguagem, carrega em si mesma as representações sociais. 0 processo de comunicação entre as revistas e seus leitores semanalmente possui importante papel na construção das representações, pois é através da comunicação que as estas são construídas. Ainda segundo os autores, a comunicação em massa, além de construir novas representações, é responsável por reproduzir ideias provenientes do meio social, participando assim da construção e difusão de novas representações. Isto acontecia a cada vez em que novos fatos a respeito da operação Lava-Jato eram divulgados pelas revistas, pois como a operação acontece de maneira muito dinâmica, a cada nova reportagem novos fatos eram inseridos, permitindo a construção de novas representações sociais. 
A corrupção e os escândalos políticos e midiáticos estão imbricados, uma vez que a corrupção ocorrida dentro da Petrobras, a partir do momento em que se tornou pública, foi o epicentro do escândalo narrado pela mídia, corroborando com a ideia de Azevedo (2010) de que os principais fatos explorados pela mídia para a construção dos escândalos são a corrupção e o suborno político. Mas transgressões narradas pela mídia nem sempre produzem escândalos quando divulgadas ao público, e segundo Adut (2004) o status do transgressor muitas vezes pode ser determinante para o nascimento do escândalo. Este fato pode ter contribuído para o escândalo de corrupção da operação Lava-Jato ter tomado tamanha proporção, visto que seus investigados são, essencialmente, políticos e empreiteiros influentes.

A operação Lava-Jato atraiu grande atenção das duas revistas, que, junto com outros veículos, geraram agitação política e midiática, ganhando contornos, assim, de um escândalo, conforme a acepção de Adut $(2005,2008)$. Até o encerramento desta pesquisa, muitos desdobramentos continuam a perturbar a vida econômica, social e política do país, não havendo pistas suficientes que acenem para um desfecho político e legal em curto prazo. Nesse aspecto, uma questão a ser evidenciada é a função do escândalo de testar as normas sociais de modo a contribuir para sua evolução (DE BLIC; LEMIEUX, 2005), isto é, a existência ou não de uma contradição entre o ideal normativo e as práticas da sociedade brasileira.

Nossa análise identificou uma intensa comunicação pública a respeito de um acontecimento real, e não fictício, que envolve a corrupção, uma prática cujas proporções, em termos de valores e contexto político, nesse caso, causou indignação e revolta. É nesse sentido que Esser e Hartung (2004) chamam a atenção para a função do escândalo de controle social, por esse atuar na forma de sanção, o que ocorreu, no caso em questão, em relação a empresas e políticos envolvidos. Não foi objeto desta pesquisa analisar a recepção do público, o que se esperaria ser uma grande indignação coletiva, pois o escândalo revela uma ordem moral interrompida (JACOBSSON; LÖFMARCK, 2008). Essa questão merece uma análise mais aprofundada, dado o modelo institucional de organização política resultante da formação histórico-cultural do país (FAORO, 2001). No entanto, ao analisar as reportagens, vislumbramos a preferência pela satisfação dos interesses da elite administradora do país, quais sejam, os partidos políticos, os políticos e seus súditos, que não cumprem as funções de interesse coletivo.

Nesse entendimento, uma questão que vem à tona é quanto de importância as normas e os valores da sociedade brasileira conferem à corrupção, já que Silva (2013) entende que um escândalo provoca uma discussão pública de valores e normas, colocando os atores em posição de disputas para resolver conflitos entre ideias e práticas. 0 que identificamos nos repertórios interpretativos mais significativos é que o escândalo é construído pelos dois veículos não para provocar uma discussão pública sobre valores e normas quanto à corrupção, mas, sim, uma disputa político-partidária, em que o posicionamento de cada um deles revelou, em um deles (Veja), o destaque à associação do partido do governo ao esquema, e no outro (Carta Capital), a defesa de que não se trata de uma associação exclusiva com esse partido.

Conforme a literatura sobre escândalos, esses surgem quando o acordo tácito entre as partes envolvidas - que mantém o assunto em nível sigiloso - é quebrado (THOMPSON, 
2000), porém, nesse caso, conforme divulgado pelas mídias, a investigação de um caso específico acabou por levar a essa operação, sendo os acordos de delação premiada decorrentes de então. Isso não quer dizer que possamos afirmar que não houve uma intenção na divulgação desse esquema, a partir de um acordo tácito entre interessados políticos na emergência de um escândalo. Assim, o escândalo aqui analisado surgiu de uma denúncia e, ao tornar-se público, adquiriu uma dinâmica própria, assumindo o centro das atenções e, por sua natureza política, ainda que outros acontecimentos e esquemas de corrupção tenham vindo a público, a Operação Lava-Jato ainda ocupa lugar de destaque na cobertura da mídia. Era de se esperar que a divulgação desse escândalo iria abalar a reputação de todos os indivíduos envolvidos, implicando ainda em processos judiciais e perda de cargos (THOMPSON, 2000), o que ocorreu em certa medida nesse um ano após sua publicização.

O escândalo político implica que a sua discussão é a esfera política, como é o caso da Operação Lava-Jato, em que as empresas envolvidas no esquema não têm igual destaque que os políticos e partidos políticos, chegando até a mesmo a contribuir para o impeachment da presidenta Dilma Rousseff. Um dos efeitos dos escândalos políticos (CASTELLS, 2007) é afetar o processo eleitoral e a tomada de decisão do eleitor, o que é variável, pois pode provocar também indiferenças do público. Nesse caso, a eleição presidencial ocorrida em 2014 foi vencida pela candidata do PT, indicando que o escândalo não influenciou a esse ponto. No entanto, nas eleições municipais de 2016, o PT foi considerado o partido derrotado, em um resultado que pode ser associado ao escândalo. 0 segundo efeito apontado por Castells (2007) incide na prática da democracia ou ainda, um estímulo com o processo democrático, o que pode ser ilustrado com as reinvindicações ocorridas a favor da volta dos militares ao poder, por parte de determinados grupos. E, ainda, pode ser ilustrada a fragilidade da democracia brasileira, o que foi revelada com o próprio processo de impeachment desencadeado.

Os repertórios interpretativos mais significativos identificados apontaram que, ao contrário do discurso de independência e apartidarismo que a imprensa muitas vezes alega, a cobertura das duas revistas gera consequências partidárias e eleitorais (AZEVEDO, 2010), influenciando as representações sociais de uma audiência heterogênea. Esses repertórios permitem ainda a construção coletiva de novos sentidos, reproduzindo ideias e, dessa forma, constroem e difundem as representações sociais criadas sobre o fenômeno, nesse caso, 0 esquema de corrupção investigado pela Operação Lava-Jato. 0 escândalo político envolvendo a Petrobrás e outras empresas implica na aplicação de normas, e, seguindo a abordagem construtivista do escândalo (ADUT, 2004), em que os escândalos são interpretações sociais das transgressões, implica ainda na quebra de confiança dos partidos políticos, políticos e instituições (COBB; TAYLOR, 2015).

Na revista Veja, um veículo que se posiciona em oposição ao PT, partido do governo à época, os repertórios evidenciam esse posicionamento. Na revista Carta Capital, veículo que se posiciona contrariamente à Veja, os três repertórios tentam desconstruir o escândalo, ora defendendo que a corrupção não é exclusividade do PT, ora atacando que a operação e a mídia "nativa" são instrumentos para atacar o partido do governo.

Uma questão a ser levantada com base nos resultados desta pesquisa refere-se às implicações das representações difundidas por esses repertórios interpretativos, visto sua influência na criação e reprodução de outras representações sociais. Esse escândalo teria 
potencial para ensejar uma discussão mais ampla na sociedade sobre o processo democrático e sobre a corrupção no país, cujos níveis são alarmantes. Isso não aconteceu, ou seja, os repertórios interpretativos mais significativos das revistas analisadas enfatizam as suas posições ideológicas, e, mesmo que o escândalo tenha sido produzido por uma transgressão real, o veículo que recebe e divulga a notícia constrói o escândalo, influenciando as representações sociais da audiência.

Ao se distanciar da compreensão daquilo que seja considerado corrupção, a mídia analisada não contribui para gerar as mudanças que são necessárias para uma transformação social. O cidadão, quando bem informado sobre aquilo que é ou não corrupção, estaria mais capacitado a gerar discussões e cobrar as autoridades no sentido de realizar uma transformação social em nosso país, capaz de iniciar a limpeza da corrupção de nossa cultura.

As organizações envolvidas em um escândalo político por terem cometido uma transgressão real, como é o caso aqui analisado, são alvo de uma exposição moral cujas reações podem ser de indignação ou de indiferença, sendo assim, os escândalos devem ser vistos como uma oportunidade para esclarecimento, posicionamento ou solidificação moral (JACOBSSON; LÖFMARCK, 2008). Nesse sentido, esperam-se dos gestores que esses se posicionem assumindo a sua real participação na transgressão, contribuindo para um debate social sobre a corrupção no Brasil.

Ao colocar dois eixos teóricos, escândalos e corrupção, para analisar de que modo dois veículos constroem um escândalo de corrupção, ultrapassamos as fronteiras de pesquisas midiáticas para trazer contribuições ao campo dos estudos organizacionais, visto que os repertórios interpretativos influenciam as representações da audiência, que, nesse campo de estudos, é um objeto recorrente nas pesquisas que relacionam poder, ideologia e organizações. Ao indicar os repertórios interpretativos mais significativos, mostramos como a mídia pode influenciar a luta pelas configurações de poder, pela gestão e pela imposição da opinião pública.

Diante dessas considerações, entendemos que outras implicações decorrem da atuação da mídia na difusão de escândalos, que assinalamos como contribuições principais desta pesquisa. São contribuições para as organizações e gestão, que, para esta pesquisa, são os partidos políticos as organizações em destaque. No entanto, nossas contribuições são extensivas às outras organizações envolvidas, como as grandes empreiteiras.

\section{CONCLUSÕES}

O Brasil possui um problema crônico de corrupção, que causa diversas consequências negativas para a sociedade brasileira. A operação Lava-Jato revelou mais um capítulo dessa história, em que aqueles que são empossados pelo povo para agir em benefício comum, desvirtuam suas funções visando o benefício próprio. A operação, que começou investigando doleiros que atuavam em Curitiba, tomou proporções inesperados, descobrindo um grande esquema de corrupção operado dentro da Petrobras.

Os repertórios interpretativos identificados nas revistas Veja e Carta Capital, ao serem levados ao grande público através das reportagens, contribuem para a construção 
das representações sociais acerca do esquema de corrupção descoberto pela operação Lava-Jato, uma vez que, conforme afirmam Santos, Acioli Neto e Souza (2011), é através da comunicação que as representações são construídas. A cada nova reportagem e novos fatos divulgados, as representações existentes podem ser modificadas, e novas representações são construídas e difundidas.

Também foi possível identificar as perspectivas teóricas sobre a corrupção, bem como os componentes que formam o escândalo que abordamos em nosso referencial teórico. O escândalo da operação Lava-Jato está em constante construção e reconstrução, já que a cada nova fase, novas transgressões são descobertas, tornadas públicas, causando reações do público e consequências para os envolvidos. Estas perspectivas e componentes nos ajudam a compreender os repertórios interpretativos identificados em cada uma das revistas.

Ficou claro que os repertórios da revista Veja foram utilizados no intuito de fazer oposição frente ao governo do partido de situação, o PT. Já os repertórios da revista Carta Capital buscaram demonstrar que a corrupção é um mal geral de todos os partidos, descontruindo o escândalo defendendo que a mídia deveria apenas informar o leitor, e não tentar influenciar em favor de determinado partido ou outro.

Nossa análise oferece aos gestores públicos e privados conhecimento sobre o modo como os escândalos de corrupção são tratados por duas linhas editoriais com posicionamentos ideológicos contrários. O jornalismo é ideológico por natureza, como postulam Barreiros e Amoroso (2008), portanto, não há de se esperar imparcialidade ou isenção nas escolhas quanto ao que publicar. Ao entender como a mídia trabalha os escândalos de corrupção, os gestores adquirem embasamento para que possam analisar o impacto dos escândalos de corrupção na imagem das organizações, e assim podem se posicionar e traçar estratégias de defesa para utilizarem caso a sua organização seja alvo de um escândalo de corrupção. Através da reflexão sobre a sistemática do esquema analisado, gestores públicos e executivos podem identificar oportunidades para o desenvolvimento de políticas, regulamentações e modelos que permitam combater a corrupção e evitar que esses escândalos afetem suas organizações. Outra contribuição no âmbito da gestão é para os partidos políticos que, como organizações que são, devem estar preparados para lidar com a produção dos escândalos pela mídia, já que são os principais afetados (juntamente com seus membros) pelos efeitos negativos da repercussão dos escândalos políticos.

Ao discutir os resultados desta pesquisa, potencializamos a compreensão do modo como os crimes de corrupção são praticados e dos prejuízos causados à sociedade pelas condutas ilícitas praticadas pelas organizações e por seus membros. Ademais, possibilita aos leitores que conheçam os repertórios interpretativos que são utilizados por duas linhas editoriais ideologicamente distintas, induzindo o pensamento crítico e a reflexão sobre 0 modo como a mídia trabalha a construção dos escândalos de corrupção.

Apesar do pouco tempo em que o PT permaneceu no poder, pois, ao analisar-se a história dos governos no Brasil, vê-se que a maioria foi composta por outros partidos, parte da mídia entende que existia um projeto de poder do PT e, por esse motivo, o governo deveria ser destituído. 
Não existe posicionamento certo ou errado entre as duas visões da mídia analisada, mas, sim, visões de mundo diferentes entre si. Nós, autores, temos as nossas posições políticas e ideológicas, mas buscamos nos abster de opiniões pessoais e não tomar partido do posicionamento de uma revista ou de outra, no intuito de realizar uma análise que possa contribuir para a discussão da temática.

Como limitações deste estudo temos o período de análise, que foi apenas o primeiro ano após a deflagração da operação Lava-Jato, visto que essa ainda não foi concluída e continua produzindo resultados. Além disso, os resultados aqui apresentados são baseados nas percepções de seus autores, o que poderia ser analisado e interpretado de maneira diferente por outras pessoas.

Considerando as lacunas encontradas e as contribuições potenciais desta pesquisa, sugerimos uma agenda de pesquisa que considere: a análise da audiência; os silêncios da mídia, ou seja, fatos referentes à operação que não tiveram a atenção da mídia, uma vez que mais importante do que expor os fatos narrados é aquilo que está oculto do grande público, por interesses diversos; as consequências e custos para as empresas envolvidas; e a análise das possibilidades de associação entre cultura nacional e corrupção.

\section{REFERÊNCIAS}

ADUT, A. On scandal. Moral Disturbances in Society, Politics, and Art. New York: Cambridge University Press, 2008.

. A Theory of Scandal: Victorians, Homosexuality, and the Fall of Oscar Wilde. American Journal of Sociology, Chicago, v. 111, n.1, p. 213-248, 2005.

. Scandal as Norm Entrepreneurship Strategy: Corruption and the French Investigating Magistrates. Theory and Society, Dordrecht, v. 33, n. 5, p. 109-130, 2004.

A MARCA da ruína vai ficar. Veja, São Paulo, ed. 2368, ano 47, n¹5, p. 52-53, 09 abr. 2014.

AZEVEDO, F. Corrupção, mídia e escândalos midiáticos no Brasil. Em Debate, Belo Horizonte, v. 2, n. 3, p 14-19, 2010.

BARREIROS, T. O.; AMOROSO, L. C. Jornalismo Estrábico: VEJA e CARTACAPITAL na Cobertura do "Escândalo do Mensalão". Perspectivas de la Comunicación, v. 1, n, 1, p. 120-131, 2008.

BARROCAL, A; SERAPIÃO, F. O doleiro ecumênico. Carta Capital, São Paulo, edição 795, ano 20, no 795, p.34, 16 abr. 2014.

BATABYAL, S.; CHOWDHURY, A. Curbing corruption, financial development and income inequality. Progress in Development Studies, v. 15, v. 1, p. 49-72, 2015.

BONIN, R. É só seguir o dinheiro. Veja, São Paulo, ed. 2416, ano 48, n 10, p. 54-55, 11 mar. 2015.

$\overline{2014}$

. Delivery internacional. Veja, São Paulo, ed. 2406, ano 47, nº 53, p. 48-51, 31 dez. 
BONIN, R.; HISAYASU, A. O PT treme de novo. Veja, São Paulo, ed. 2403, ano 47, nº 50, 10 dez. 2014.

BORGES DE FREITAS, A. Traços culturais para uma análise organizacional. In: PRESTES MOTTA, F. C.; CALDAS, M. Cultura organizacional e cultura brasileira. São Paulo: Atlas, 1997.

BRAUN, V.; CLARKE, V. Using thematic analysis in psychology. Qualitative Research, v. 3, n. 2, p. 77-101, 2006

BREI, Z. A. Corrupção: dificuldades para definição e para um consenso. Revista de Administração Pública, v. 30, n. 1, p. 64-77, 1996.

CARTA, M. As mãos sujas. Carta Capital, São Paulo, ed. 827, ano 20, nº 827, p. 16, 26 nov. 2014. $\overline{2015}$.

. 0 país insensato. Carta Capital, São Paulo, ed. 841, ano 21, n 841, p. 14, 18 mar.

CASTELLS, M. Communication, Power and Counter-power in the Network Society. International Journal of Communication, Los Angeles, v. 1, p. 238-266, 2007.

CHAIA, V.; TEIXEIRA, M. A. Democracia e escândalos políticos. São Paulo em Perspectiva, São Paulo, v. 15, n. 4, p. 62-75, 2001.

CHOULIARAKI, L.; MORSING, M. Introduction: Towards an Understanding of the Interplay between Media and Organizations. In: CHOULIARAKI, L.; MORSING, M. Media, Organizations, Identity. London: Palgrave Macmilian, 2010.

COBB, M. D.; TAYLOR, A. J. An Absence of Malice: The Limited Utility of Campaigning Against Party Corruption. American Politics Research, v. 43, n. 6, p. 923-951, 2015.

COSTAS, R. Escândalo da petrobras 'engoliu 2,5\% da economia em 2015'. 2 dez. 2015 Disponível em: http://www.bbc.com/portuguese/noticias/2015/12/151201_lavajato_ru. Acesso em: 08 dez. 2015.

DE BLIC, D.; LEMIEUX, C. Le scandale comme épreuve: elements de sociologie pragmatique. Politix, Paris, n. 71, p. 9-38, 2005.

ESSER, F.; HARTUNG, U. Nazis, Pollution, and no Sex: Political Scandals as a Reflection of Political Culture in Germany. American Behavioral Scientist, v. 47, n. 8, p. 1040-1071, 2004.

FAORO, R. Os donos do poder: formação do patronato político brasileiro. $3^{a}$ ed. revista. São Paulo: Globo, 2001.

FILGUEIRAS, F. A corrupção na política: perspectivas teóricas e metodológicas. Cadernos Cedes, Juiz de Fora, nº 5, p.1-29, 2006.

FLICK, U. Introdução à pesquisa qualitativa. $3^{\text {a }}$ ed. Porto Alegre: Artemed, 2009.

FLORENTINO, R. Saindo de cena: Parlamentares que desistem da disputa eleitoral (19902006). Revista de Sociologia e Política. Curitiba, v. 16, v. 30, p. 45-63, 2008.

GASPAR, M. A cifra que desafia Bendine. Veja, São Paulo, ed. 2413, ano 48, n 7, p. 52-55, 18 fev. 2015. 
GASPAR, M.; RANGEL, R. Ninguém desconfiou? Veja, São Paulo, ed. 2391, ano 47, nº 38, p. 72-73, 17 set. 2014.

GARDINER, J. A. Defining Corruption. In: HEIDENHEIMER, A. J.; JOHNSTON, M. (eds.). Political corruption: concepts and contexts, London: Transaction Publishers, 2002, p. 2540.

GOMES, J. V. L. Corrupção em perspectivas teóricas. Teoria e Cultura, Juiz de Fora, v. 5, n. 1 e 2, p. 21-33, jan./dez. 2010.

HEIDENHEIMER, A. J. Perspectives on the Perception of Corruption. In: HEIDENHEIMER, A. J.; JOHNSTON, M.; LEVINE, V. T. Political Corruption: A Handbook. New Brunswick: Transaction Books, 1989, p. 149-163.

Political corruption readings in comparative analysis. New Brunswick: Transaction Books, 1970.

HISAYASU, A.; RANGEL, R. O consultor do esquema. Veja, São Paulo, ed. 2413, ano 48, no 7, p. 50-51, 18 fev. 2015.

HODGKINSON, P. The sociology of corruption - some themes and issues. Sociology, v. 31, n. 1, p. 17-35, 1997.

HUNTINGTON, S. P. A Ordem Política nas Sociedades em Mudança. São Paulo: Ed. USP. 1975.

IJEWEREME, O. B. Anatomy of Corruption in the Nigerian Public Sector: Theoretical Perspectives and Some Empirical Explanations. Sage Open, v. 5, n. 2, p. 1-16, 2015.

JACOBSSON, K.; LÖFMARCK, E. A sociology of scandal and moral transgression the swedish 'nannygate' scandal. Acta Sociologica, v. 51, n. 3, p. 203-216, 2008.

MAIEROVITCH, W.F. Mãos limpas e lava jato. Carta Capital, São Paulo, edição 829, ano 20, no 829, p.23, 10 dez. 2014.

. Choro e ranger de dentes. Carta Capital, São Paulo, edição 841, ano 21, n 841, p.17, 18 mar. 2015.

MARQUES, H; RANGEL, R. O objetivo é o caixa dois. Veja, São Paulo, edição 2369, ano 47, n 16, p.66-71, 16 abr. 2014.

MARTINS, J. A. Corrupção. São Paulo: Globo, 2008.

MPF COMBATE A CORRUPÇÃO. Caso lava jato. 2015. Disponível em: http://lavajato.mpf. mp.br/entenda-o-caso. Acesso em: 25 nov. 2015.

A Lava Jato em números. 2016. Disponível em: http://lavajato.mpf.mp.br/atuacao-na-1a-instancia/resultados/a-lava-jato-em-numeros-1. Acesso em 01 abr. 2016.

NYE, J. S. Corruption and Political Development: A Cost-Benefit Analysis. American Political Science Review, Baltimore, v. 61, n. 2, p. 417-427, 1967.

OBEROI, R. Mapping the Matrix of Corruption: Tracking the Empirical Evidences and Tailoring Responses. Journal of Asian and African Studies. v. 49, n. 2, p. 187-214, 2014.

ORLANDI, E. P. Análise de Discurso: princípios \& procedimentos. Campinas: Pontes, 2009. 
PETRY, A. Certezas sem base. Veja, São Paulo, ed. 2416, ano 48, n 10, p.58-59, 11 mar. 2015.

POTTER, J.; WETHERELL, M. Discourse and Social Psychology. London: Sage, 1987.

PUGLISI, R.; SNYDER, J. Newspaper Coverage of Political Scandals. The Journal of Politics, Austin, v. 73, n. 3, p. 931-950, 2011.

RANGEL, R. Nomes sob suspeita. Veja, São Paulo, ed. 2416, ano 48, nº 10, p. 48-53, 11 mar. 2015.

RENNÓ, L. R. Escândalos e voto: As eleições presidenciais brasileiras de 2006. Opinião Pública. Campinas, v. 13, n. 2, p. 260-282, 2007.

SAKATE, M. Abuso 3x1 corrupção. Veja, São Paulo, ed. 2401, ano 47, n 48, p.78-79, 26 nov. 2014.

SANTOS, M. de F. de S.; ACIOLI NETO, M. de L.; SOUZA, Y. S. de O. Adolescência em revistas: um estudo sobre representações sociais. Psicologia: teoria e prática, v. 13, n. 2, p. 103-113, 2011.

SERAPIÃO, F. A enésima tentativa. Carta Capital, São Paulo, ed. 821, ano 20, nº 821, p. 28-29, 15 out. 2014 a.

- Que a farsa não atrapalhe. Carta Capital, São Paulo, ed. 824, ano 20, nº 824, p. 36-38, 05 nov. 2014b. 2014c.

. Juízo final? Carta Capital, São Paulo, ed. 827, ano 20, nº 827, p. 20-27, 26 nov.

Retórica defensiva. Carta Capital, São Paulo, ed. 835, ano 21, n 835, p. 44-45, 04 fev. 2015a.

. A lava jato abre o leque. Carta Capital, São Paulo, ed. 842, ano 21, nº 842, p. 28-32, 25 mar. 2015b.

SILVA, M. Corrupção: tentativa de uma definição funcional. Revista de Administração Pública, Rio de Janeiro, v. 28, n. 1, p. 18-23, 1994.

SILVA, P. J. et al. A ação corrupta em uma organização multinacional: uma análise sob a ótica da abordagem construcionista. REAd. Revista Eletrônica de Administração, Porto Alegre, v. 11, n. 6, p. 1-27, nov./dez. 2005. Disponível em: http://seer.ufrgs.br/index.php/ read/article/view/40614/25828. Acesso em: 10 mar. 2016.

SILVA, T. A pesquisa sobre escândalo político: panorama de 10 anos. Revista Fronteiras estudos midiáticos, São Leopoldo, v. 15, n. 3, p. 160-169, 2013.

SPINK, M. J.; FREZZA, R. M. Práticas discursivas e produção de sentidos: a perspectiva da psicologia social. In: SPINK, M. J. (Org.). Práticas discursivas e produção dos sentidos no cotidiano: aproximações teóricas e metodológicas. Rio de Janeiro: Centro Edelstein de Pesquisas Sociais, 2013, p. 22- 41.

SPINK, M. J.; MEDRADO, B. Produção de sentidos no cotidiano: uma abordagem teórico-metodológica para análise das práticas discursivas. In: SPINK, M. J. (Org.). Práticas 
discursivas e produção de sentidos no cotidiano: aproximações teóricas e metodológicas. Rio de Janeiro: Centro Edelstein de Pesquisas Sociais, 2013.

TRANSPARENCY INTERNATIONAL. What is corruption?. 2015. Disponível em: https:// www.transparency.org/what-is-corruption. Acesso em: 01 abr. 2016.

. Corruptions Perceptions Index 2015. 2016. Disponível em: https://www.transparency.org/cpi2015\#map-container. Acesso em 02 abr. 2016.

THOMPSON, J. B. Political scandal: Power and visibility in the media age. Cambridge: Polity Press, 2000.

Data de Submissão: 15/02/2017.

Data de Aprovação: 18/04/2018. 